\title{
Carnauba (copernicia prunifera) straw as an alternative bedding material for dairy cows housed in a Compost barn system
}

\author{
[Bagana de carnaúba como material de cama alternativo para vacas leiteiras alojadas \\ em sistema Compost barn] \\ L.C. Sampaio $^{1(\mathbb{D})}$, M.S.M. Peixoto $^{1 *(D)}$, J.A.D. Barbosa Filho ${ }^{(\mathbb{D})}$, F.A. Damasceno $^{2}$ (D), \\ N.A.F. Machado ${ }^{(\mathbb{D})}$, L.B.S. Costa ${ }^{1}$ (D) K.P.L. Oliveira ${ }^{1}$ \\ ${ }^{1}$ Universidade Federal do Ceará, Departamento de Engenharia Agrícola, Fortaleza, CE, Brasil \\ 2Universidade Federal de Lavras, Departamento de Engenharia, Lavras, MG, Brasil
}

\begin{abstract}
The replacement of bedding in compost dairy barns (CB) comprises a recurrent management practice, but bedding materials are often not readily available in all regions and the choice of alternative materials is necessary. The objective was to evaluate the thermal attributes of carnauba straw (CS) bedding in compost dairy barn facilities. Environmental monitoring operations were performed at a commercial farm located in Northeast Brazil. Mini weather stations were used to evaluate environmental variables. The THI was evaluated as one of the comfort parameters. Analysis of the spatial distribution of bed surface temperature (BST) in the CB was performed using geostatistical techniques. The cows remained out of the comfort zone according to THI results. The BST indicated satisfactory performance and from the thermal point of view can be used as alternative bedding material in CB facilities. However, it was observed that the CS showed fast biomass degradation compared to conventional materials, widely known. In addition, inadequate temperature values $\left(<45^{\circ} \mathrm{C}\right)$ were found in the deeper of the CS bed, signaling higher risks of pathogenic microbial activity. Additional studies are needed for searching the proper management plans that increase the life span of the bed formed by carnauba straw.
\end{abstract}

Keywords: dairy cow, thermal comfort, copernicia prunifera, geostatistics

\section{RESUMO}

A reposição de cama na instalação Compost Barn $(C B)$ compreende uma prática recorrente de manejo, porém os materiais de cama muitas vezes não estão facilmente disponíveis em todas as regiões, sendo necessária a adoção de materiais alternativos. Objetivou-se avaliar os atributos térmicos da cama à base de bagana de carnaúba $(B C)$ para instalações $C B$. Foram realizadas operações de monitoramento ambiental em uma fazenda comercial situada no nordeste do Brasil. Miniestações meteorológicas foram utilizadas para avaliação de variáveis ambientais. O ITU foi avaliado como um dos parâmetros de conforto. A distribuição espacial da temperatura superficial da cama (TSC) no galpão foi analisada usando técnicas da geoestatística. As vacas mantiveram-se fora da zona de conforto, conforme resultados do ITU. A TSC indicou desempenho satisfatório e, do ponto de vista térmico, pode ser utilizada como material alternativo para cama em instalações CB. Entretanto, observou-se que a BC apresentou rápida degradação da biomassa em comparação a materiais convencionais, amplamente conhecidos. Além disso, valores inadequados de temperatura $\left(<45^{\circ} \mathrm{C}\right)$ foram encontrados nas camadas profundas da cama de $B C$, sinalizando maiores riscos de atividade microbiana patogênica. Estudos adicionais tornam-se necessários para a busca de planos de manejo que aumentem o tempo de vida útil da cama formada por bagana de carnaúba.

Palavras-chave: vacas leiteiras, conforto térmico, Copernicia prunifera, geoestatística

*Corresponding author: simone.neambe@gmail.com

Submitted: May 26, 2021. Accepted: June 8, 2021. 


\section{INTRODUCTION}

Compost barn (CB), which is a relatively new system worldwide, has emerged as an alternative to conventional systems used in dairy farming (Bewley et al., 2017). The large resting area observed in these facilities allows the free movement of cattle, however, the resting behavior is influenced by construction characteristics, as well as by microclimate thermal conditions, which can compromise production (Cook, 2020). The maintenance of the good conditions of the rest area is done, mainly, from measurements of the temperature of the bedding (Janni et al., 2006).

The choice of bedding type is a key issue in Compost Barns (CB) systems. Factors such as constant product availability, price and purchase logistics are seen by the producer as considerable management challenges, with sawdust being generally the most used material on farms (Barberg et al., 2007; Oliveira et al., 2019). However, materials such as sawdust or wood shavings have a high cost for producers in some regions, thus increasing interest in alternative bedding materials (Shane et al., 2010). Brazilian producers have used materials such as peanut shells, coffee shell, and rice straw, according to the availability of these materials in their regions (Damasceno, 2020). Studies have shown the use of alternative materials in Brazil (Oliveira et al., 2019; Piovesan and Oliveira, 2020; Valente et al., 2020).

In view of this, the carnauba straw residue (Copernicia prunifera (Miller) H.E. Moore) emerges as an alternative material, being an agroindustrial byproduct originated from the straw drying process and wax extraction. Carnauba is a palm tree commonly found in the northeast of Brazil, representing important socioeconomic value to the region and that offering several applications, so that the carnauba straw has been used as soil cover, or even in the composting process (Gomes et al., 2009; Silva et al., 2019).

However, to use this resource it is necessary to collect scientific data, which serves as performance parameters in comparison to other alternative materials, as well as to understand its dynamics in the composting process and its thermal characteristics in a tropical climate. In this perspective, the objective was to evaluate the use of carnauba straw as an alternative bedding material for the comfort of dairy cows in the Compost barn systems.

\section{MATERIALS AND METHODS}

The research was conducted from May to September 2018 in a Compost Barn for dairy cattle, located in Russas, Ceará, Brazil ( $4^{\circ} 54^{\prime} 18.3$ "S 37057'05.0 "W). According to Köppen, the region's climate is classified as tropical with a dry season, with an average annual rainfall of $654 \mathrm{~mm}$. The experiment followed the recommendations of Ethics Committee on the Use of Animals (CEUA/UFC), under protocol number 8288100518.

The carnauba straw (CS) was processed on the farm itself, which has the practice of mixing the straw with sand in a 50:50 proportion. This material was distributed as the bedding of the barn in a $525 \mathrm{~m}^{2}$ area. Only one replacement of the material was performed as an addition. The facility had a concrete feed alley, which separated the barn into two resting area, which included two water troughs each, in addition to having 5.0 meters of height ceiling and eaves of 1.5 meters. The roof pitched, formed by galvanized tile type, had an opening in the roof ridge. The shed had $795.6 \mathrm{~m}^{2}$ and was composed of eight fans (Magnum 60, 1 hp, 86.000m 3/h, 45m 3/watt, 520 RPM) distributed evenly, that remained connected throughout the experimental research.

The number of housed animals was 80,58 , and 55 cows for the 1st, 2nd, and 3rd phase, respectively. There was no interference in the densification of cows in the resting area and in the handling of bedding. The crossbreed cows (3/4 Holstein x 1/4 Gir) weighted $430 \mathrm{~kg} \pm 2.40 \mathrm{~kg}$, presenting average production of $20 \pm 3 \mathrm{~L}$ of milk per day. The bedding management was performed twice a day, at $04 \mathrm{~h}$ and $16 \mathrm{~h}$, using a rotary hoe (LUMA $囚$, model ROTOPEC-2000, Itapira-SP, Brazil) attached to a tractor.

In this study, the collection of environmental data and bed temperature was divided into three phases, performed during five consecutive days in each experimental phase: 1 st phase (15 - 20 days), 2nd phase (72 - 77 days) and 3rd phase (121 - 126 days).

The environmental data were collected by monitoring air temperature (AT) and relative 
humidity $(\mathrm{RH})$ using three mini weather stations and Data Loggers (Onset ${ }^{\circledR}$, U23-001 HOBO ${ }^{\circledR}$ Pro v2, Cape Cod, Massachusetts, USA), measurements were taken every 10 minutes. The other data were collected around $9 \mathrm{~h}$ and $15 \mathrm{~h}$, at the time that the cows were moving to the milking parlor. The microclimate characteristics of the facility were determined by the Temperature and Humidity Index (THI) with the formula adapted by Baccari Júnior et al. (1983), according to equation 1 .

$\mathrm{THI}=\mathrm{Tdb}+0.36 . \mathrm{Tdp}+41.2$

Where: $\mathrm{Tdb}$ is the dry bulb temperature, ${ }^{\circ} \mathrm{C}$; Tdp is the dew point temperature, ${ }^{\circ} \mathrm{C}$.

The bed surface temperature (BST) was determined at 60 equidistant points using a 4,800pixel resolution thermographic camera (Fluke ${ }^{\circledR}$ model TiS10, Everett, WA, USA) at a fixed distance of one meter between the observer and the target as described by Peixoto et al. (2019) and Silva et al. (2020). The analysis of the thermal images was performed using the software SmartView 4.3 (Fluke ® Systems Inc.).

The wind speed (WS) was determined using a digital propeller anemometer (Minipa model MDA-20, Houston, Texas, USA), measured at bed height (Black et al., 2013).

The bed internal temperature (BIT) was measured in the same 60 points, using a digital thermometer, skewer type (Lotus ${ }^{\circledR}$, TP10, Serra, ES, Brazil), at a depth of $20 \mathrm{~cm}$ (Oliveira et al., 2019). The visual aspect of the bed was monitored in order to adjust possible replacement with carnauba straw.

The data were submitted to analysis of variance by the method of least squares using the GLM procedure in the SAS software (v9). 2, SAS, 2010, Cary, NC, USA) according to the statistical model: $\mathrm{Y}_{\mathrm{ijk}}=\mu+\mathrm{F}_{\mathrm{i}}+\mathrm{T}_{\mathrm{j}}+\mathrm{I}_{\mathrm{ij}}+\varepsilon_{\mathrm{ijk}}$;

where $Y_{i j}=$ dependent variable; $\mu$ is the effect of the general mean; $F_{i}$ is the effect of the $i$-th phase of the bed cycle; $T_{j}$ is the effect of the $j$-th shift; $I_{i j}$ is the interaction between phase and shift, and $\varepsilon$ is the experimental error. A comparison of means was performed by the Tukey test $(\mathrm{P}<0.05)$.
Semi variograms for BST evaluation were analyzed based on the stationarity assumptions of the intrinsic hypothesis and the calculation of semi variance (Vieira, 2000), according to equation 2, for the evaluation of the BST variable.

$\bar{\gamma}(\mathrm{h})=\frac{1}{2 \mathrm{n}_{(\mathrm{k})}} \sum_{\mathrm{i}=1}^{\mathrm{N}(\mathrm{k})}\left[\mathrm{Z}\left(\mathrm{s}_{\mathrm{i}}\right)-\mathrm{Z}\left(\mathrm{S}_{\mathrm{i}}+\mathrm{h}\right)\right]^{2}$

Where: $\mathrm{h}$ is the separation distance between the measurements; $\mathrm{N}(\mathrm{h})$ is the number of experimental pairs of measured data of $Z\left(x_{i}\right)$ and $Z\left(x_{i}+h\right) ; Z\left(x_{i}\right)$ is the value of the variable for nonestimated (true) $x_{i}$ position considered as a random variable, function of the sample position $x ; \mathrm{Z}\left(\mathrm{x}_{\mathrm{i}}+\mathrm{h}\right)$ is the value of the same variable at position $x_{i}+h$ in any direction.

The GS+ (Geostatistical for Environmental Sciences) software, version 5.0 (GS+2000), was used to adjust the spatial modeling. The spatial variability and the spatial dependence index were estimated by the relation $[\mathrm{C} /(\mathrm{C} 0+\mathrm{C})]$, where $\mathrm{Co}+\mathrm{C}$ is the sill; $\mathrm{Co}$ is the nugget effect, and $\mathrm{C}$ is the structural variance. The spatial dependence index (SDI) was analyzed using the Zimback classification (2001), being the SDI ranges $\leq 25 \%$ semi variograms with low spatial dependence, $25 \%<\mathrm{SDI}<75 \%$ moderate spatial dependence, and $\geq$ strong spatial dependence. The values of the BST were analyzed using geostatistical techniques, with the elaboration of thematic maps interpolated by the method of ordinary kriging using Surfer ${ }^{\circledR}$ (Golden Software, Inc.), Version 10 .

\section{RESULTS AND DISCUSSION}

The best performance of the bed was verified in the first phase of collection, in which the average BST during the afternoon shift, considered the most critical for the animals, did not show an accentuated value in relation to other phases, even with the smallest space per cow and low wind speed. Although the bed was in the initial process of composting, it can be considered that the association of factors, lower AT and higher UR, contributed to more favorable values of BST and BIT, considering the regions of semiarid climate (Table 1). 
Table 1. Environmental parameters and thermal attributes of the bedding formed by carnauba straw during 3 management phases

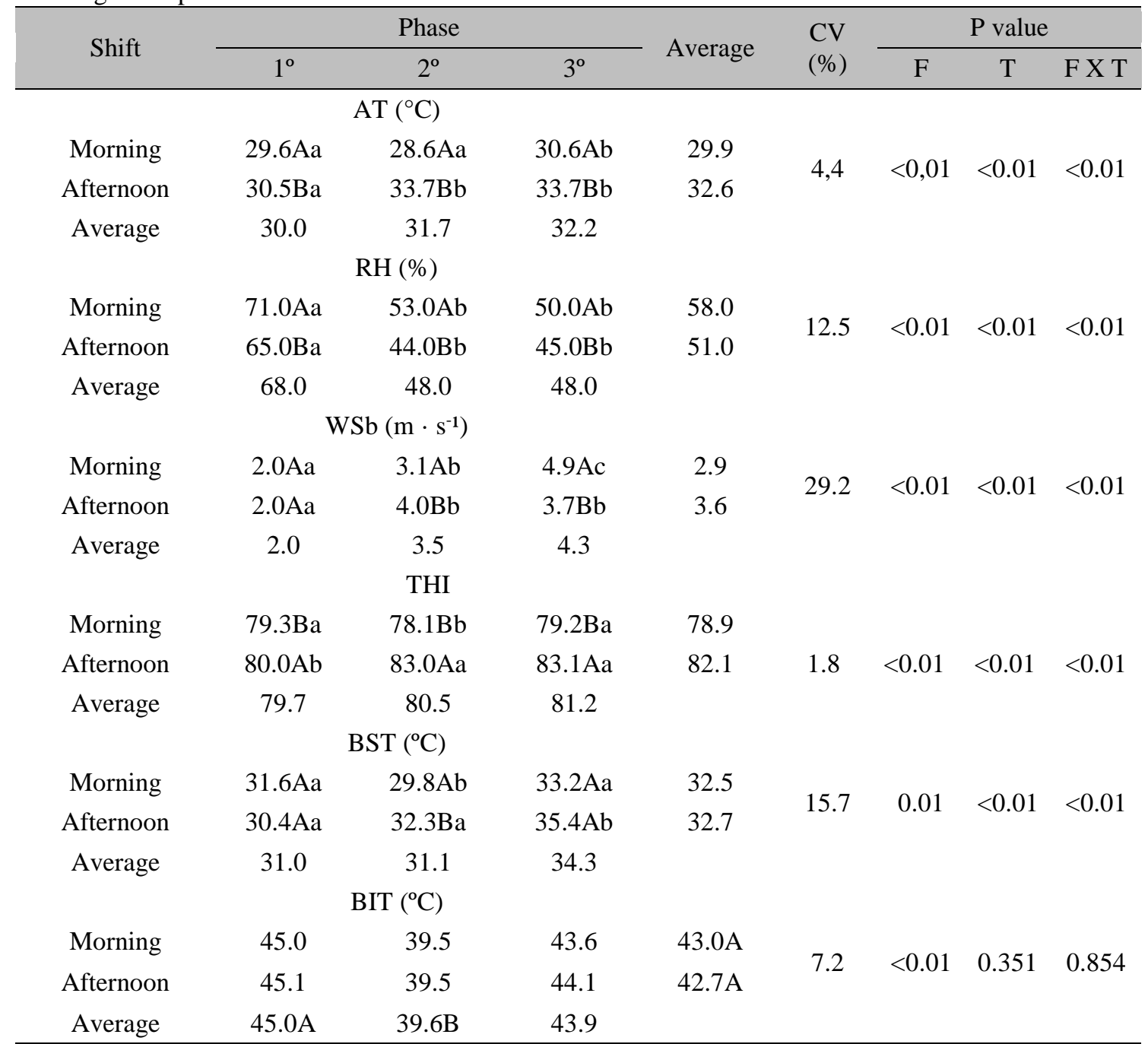

AT: air temperature $\left({ }^{\circ} \mathrm{C}\right)$; RH: relative humidity (\%); WSb: wind speed at bed height (m.s-1); BST: bed surface temperature $\left({ }^{\circ} \mathrm{C}\right)$; BIT: bed internal temperature $\left({ }^{\circ} \mathrm{C}\right)$. Averages followed by equal letters, upper case in the column and lower case in the line, do not differ from each other by the Tukey test at $5 \%$ significance.

The variation of the BST was smaller between the shifts of the first phase (Table 2). Given this, the best results can also be related to the higher internal bed temperature (BIT), which indicates that, in this condition, the bedding remained within the temperature range considered ideal, as recommended by Janni et al. (2006). However, in a study conducted by Silva et al. (2020) in a compost barn in the Brazilian semiarid region, the authors observed values bed surface temperature below $30{ }^{\circ} \mathrm{C}$, it differed from the present study.
The lower temperature range (AT) observed between shifts in the first phase may have provided the animals a more comfortable surface to lie on throughout the day, allowing more efficient thermal exchanges (Peixoto et al., 2019). On the other hand, high temperatures and relative humidity conditions for semiarid conditions can be critical in the afternoon, when the environmental temperatures are higher and the recommended range maximum temperature range $29^{\circ} \mathrm{C}$, for crossbreed cows (Linhares et al., 2015). 
Carnauba (copernicia prunifera)...

Table 2. Descriptive analysis of the internal and surface temperature data of the bed in the morning and afternoon shifts

\begin{tabular}{ccccccccc}
$\begin{array}{c}\text { Temperature } \\
\text { variable }\end{array}$ & Shift & Average & $\begin{array}{c}\text { Standard } \\
\text { deviation }\end{array}$ & Variance & CV & Range & Asymmetry & Kurtosis \\
\hline \multirow{2}{*}{ BST } & Morning & 31.59 & 4.85 & 23.50 & 15.3 & 27.40 & 2.49 & 7.29 \\
& Afternoon & 30.35 & 3.25 & 10.55 & 10.7 & 13.55 & -0.52 & -0.31 \\
BIT & Morning & 44.95 & 3.59 & 12.91 & 8.0 & 15.50 & -0.27 & -0.6 \\
& Afternoon & 45.09 & 3.28 & 13.91 & 8.3 & 16.20 & -0.43 & -0.67 \\
& & & & $2^{\circ}$ phase & & & \\
BST & Morning & 29.79 & 7.12 & 50.64 & 23.9 & 36.75 & 2.85 & 7.92 \\
& Afternoon & 32.29 & 3.66 & 13.42 & 11.3 & 16.03 & 1.43 & 1.99 \\
BIT & Morning & 39.48 & 2.47 & 6.11 & 6.3 & 10.65 & 0.1 & -0.66 \\
& Afternoon & 39.64 & 2.04 & 4.16 & 5.1 & 8.40 & -0.19 & -0.9 \\
& & & & $3^{\circ}$ phase & & & & \\
\multirow{2}{*}{ BST } & Morning & 33.15 & 6.66 & 44.39 & 20.1 & 31.95 & 2.56 & 6.1 \\
& Afternoon & 35.40 & 3.22 & 10.40 & 9.1 & 17.53 & 2.11 & 5.27 \\
BIT & Morning & 43.62 & 3.14 & 9.85 & 7.2 & 12.48 & 0.27 & -0.74 \\
& Afternoon & 44.13 & 3.12 & 9.75 & 7.1 & 12.40 & 0.06 & -1.01 \\
\hline
\end{tabular}

BST: bed surface temperature; BIT: bed internal temperature; CV: coefficient of variation.

In semiarid climate conditions, the animals are almost always exposed to temperatures near or above the limit of the range considered ideal, using the evaporative thermolysis as the most efficient homeostatic mechanism. Such condition indicated an accentuated THI result during all phases (>80). In studies conducted in facilities compost barn in Brazilian semiarid region (Silva et al., 2020; Machado et al., 2021) were reported similar findings. The authors observed the THI oscillated between values of 79 and 80 , at the hottest times of the day, which is classified as danger thermal stress condition for dairy cows (Hahn et al., 2009). Thus, although the first collection phase had presented lower THI, the cows were in thermal stress during the whole experimental period.

The increase in BST is associated with the increase in air temperature so that the association with other environmental factors leads to the dissipation of heat by evaporative means (Eckelkamp et al., 2016; Dimov et al., 2017). A significant statistical difference in BST between shifts could only be seen in the second experimental phase $(\mathrm{p}<0.05)$, when such variable was below air temperature (AT) in the afternoon shift. This approach is consistent with findings by Silva et al. (2020) who observed that the air temperature had a strong relationship with the bed temperature. In the third phase, bed temperature was higher than the air temperature, indicating a more active composting process (Leso et al., 2018).

The fast degradation of the material (CS) showed the relevance of investigating how the weather conditions influence the longevity of the bedding, which was maintained in the facilities for a period of approximately 140 days. According to studies proposed by Janni et al. (2006), this period is considered short, since bedding material can be changed between 6 and 12 months.

The observed bedding material (CS) visual degradation and its signs of compacting were seen as worrying factors by the farm administrator, who planned the complete removal of the bed after the third phase of analysis due to the concern with the dirt score of the animals (Fig. 1). 

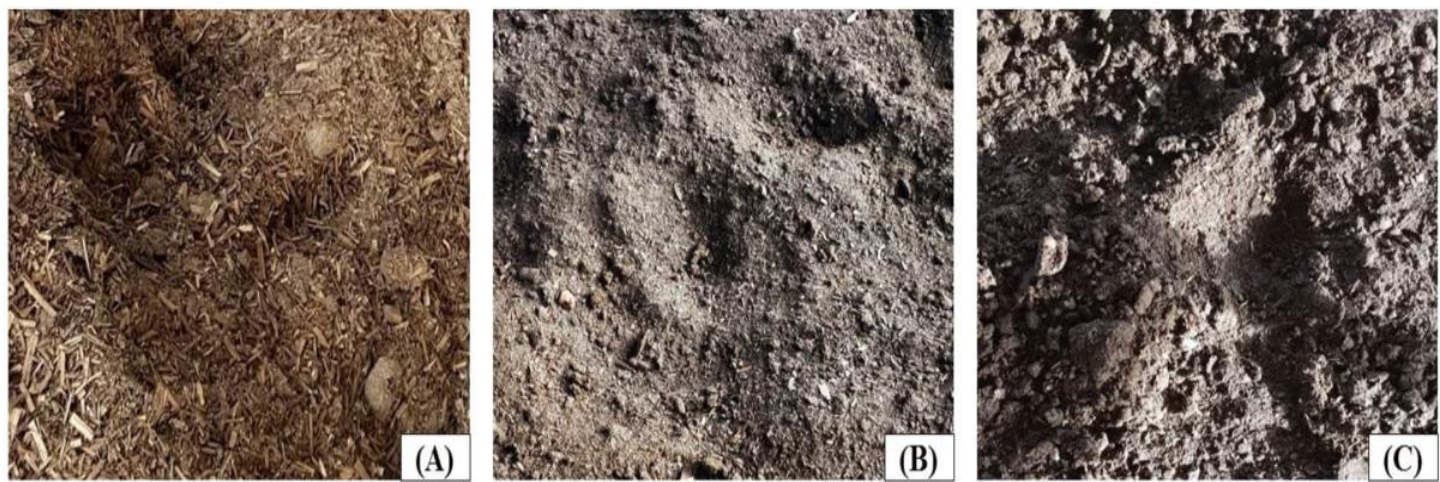

Figure 1. The physical aspect of the bed formed by carnauba straw in three phases of use: (A) 20 days, (B) 77 days, (C) 126 days.

According to Damasceno (2020), the studies conducted in Brazil are still scarce in terms of efficiency and quality of alternative materials for the bed available in each region. Piovesan and Oliveira (2020) reported in studies in southern Brazil, that the use oatmeal husk as alternative material resulted significant increase in bedding fermentation and BIT increase, indicating favorable results.

In the current study, the constructive aspect of the barn also contributed to the heating of the bed at borders of the rest area. Similar findings were reported by Mota et al., 2019. The dimensioning of the eaves allowed the direct entry of solar radiation more intensely during morning shift, this result which may explain BST coefficients of variation values $(\mathrm{CV}>15 \%)$. However, Silva $e t$ al. (2020), studied the spatial variability of the BST in Brazilian semiarid region and low results $(\mathrm{CV}<12 \%)$ were observed at all experimental periods. According to the authors, the uniform distribution of BST was justified by the porosity of the analyzed material (sawdust). From the elaboration of experimental semi variograms, which were adjusted to linear, spherical, and exponential models (Table 3), it was possible to understand the thermal behavior of the bed, after obtaining the spatial distribution maps.

Table 3. Estimated models and parameters of the experimental semi variograms for evaluation of the bed surface temperature (BST, ${ }^{\circ} \mathrm{C}$ ), in the Compost barn system, during the morning and afternoon shifts

\begin{tabular}{cccccccc}
\hline Phase & Attributes & Model & Co & Co + C & a & C/(C+Co).100 & $\mathrm{R}^{2}$ \\
\hline \multirow{2}{*}{1} & BST morning & Linear & 247179.00 & 30.45 & 35.18 & 91.9 & 0.942 \\
& BST afternoon & Spheric & 72800.00 & 3.44 & 74.14 & 78.9 & 0.612 \\
\multirow{2}{*}{2} & BST morning & Spheric & 2000.00 & 5.04 & 55.28 & 99.6 & 0.952 \\
& BST afternoon & Linear & 1000.00 & 20.11 & 50.39 & 100 & 0.952 \\
\multirow{2}{*}{3} & BST morning & Spheric & 140000.00 & 103.80 & 60.13 & 98.7 & 0.953 \\
& BST afternoon & Exponential & 1000.00 & 15.99 & 21.69 & 99.9 & 0.978 \\
\hline
\end{tabular}

C0: nugget effect; $\mathrm{C} 0+\mathrm{C}$ : sill; a: range; $\mathrm{R}^{2}$ : coefficient of determination.

According to the classification suggested by Zimback (2001), there is a strong spatial dependence between the points collected for all phases of the study, in both shifts. The geostatistical analysis allowed to characterize the distribution of surface temperature throughout the entire barn, as well as the impact on animal comfort, providing an understanding of the influence of climatic variations and the frequency of bed replacement under thermal aspects. Therefore, this proved to be an efficient technique for analyzing the variability of the thermal conditions of bedding in Compost barn systems (Mota et al., 2019; Peixoto et al., 2019; Silva et al., 2020). The BST spatial distribution maps can be seen in Figs 2, 3. 
According to the maps presented, the spatial distribution of BST was more favorable in the first phase, even with the space of $6.6 \mathrm{~m}^{2} / \mathrm{cow}$. Emphasis can be given on the map of the afternoon shift, which showed greater uniformity of values along the barn and lower temperature values. Being this period the most critical for dairy cattle confined in the semiarid region climate. The values obtained in this study showed environmental variables have significant variations $(p<0.05)$ between shifts.

A

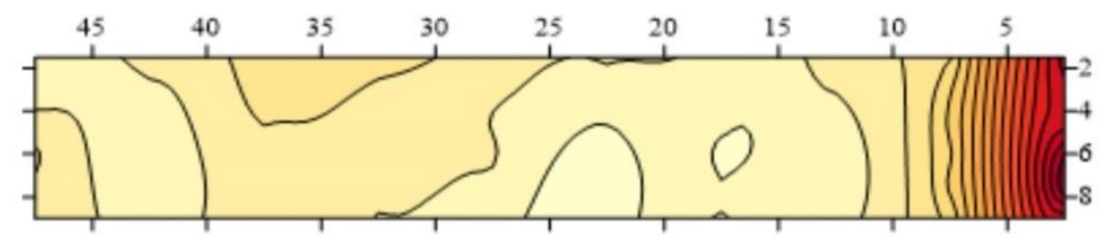

BST $\left({ }^{\circ} \mathrm{C}\right)$

28293031323334353637383940414243444546

B

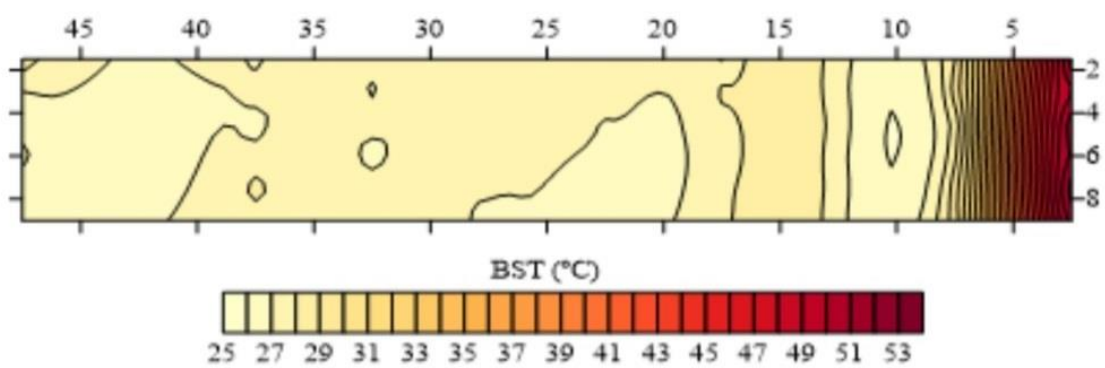

C

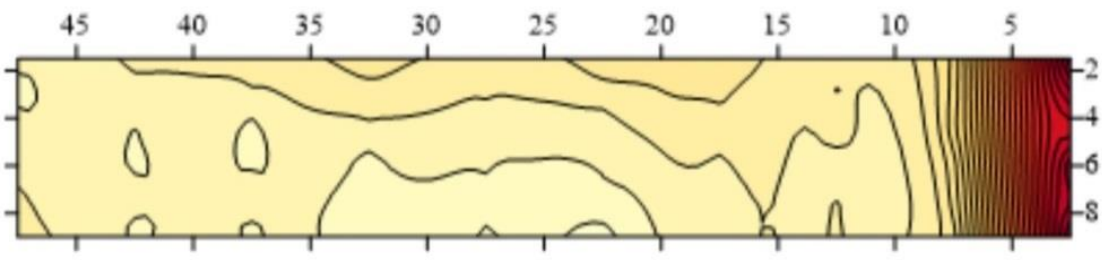

BST $\left({ }^{\circ} \mathrm{C}\right)$
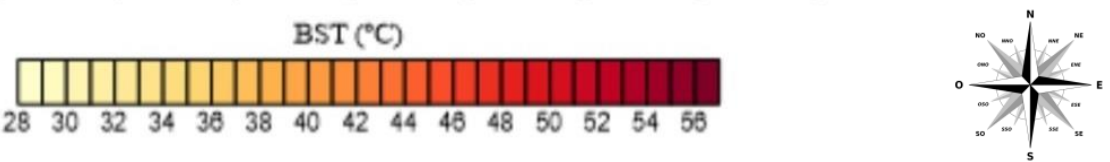

Figure 2. Spatial distribution of the surface temperature of the carnauba straw bed $\left({ }^{\circ} \mathrm{C}\right)$ in the Compost Barn, in the morning shift, in the 1st (A), 2nd (B), and 3rd (C) phase. 
A

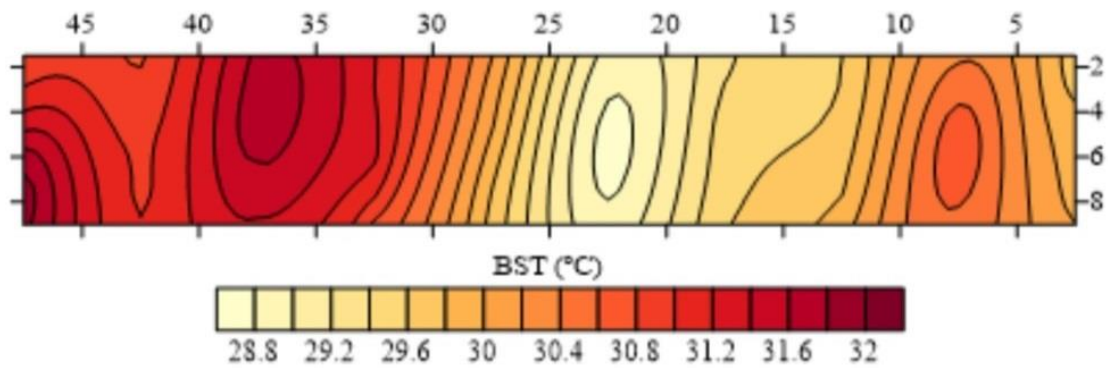

B

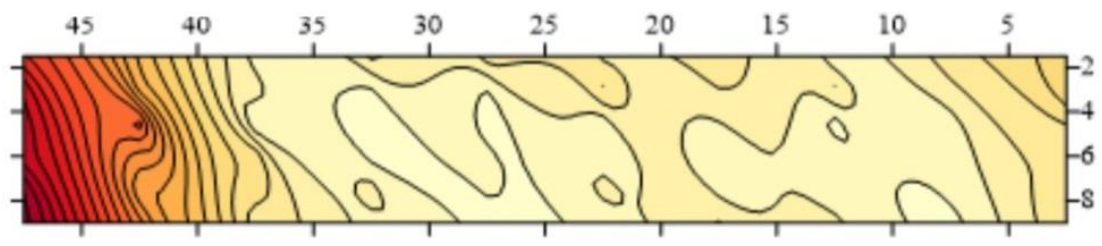

BST $\left({ }^{\circ} \mathrm{C}\right)$
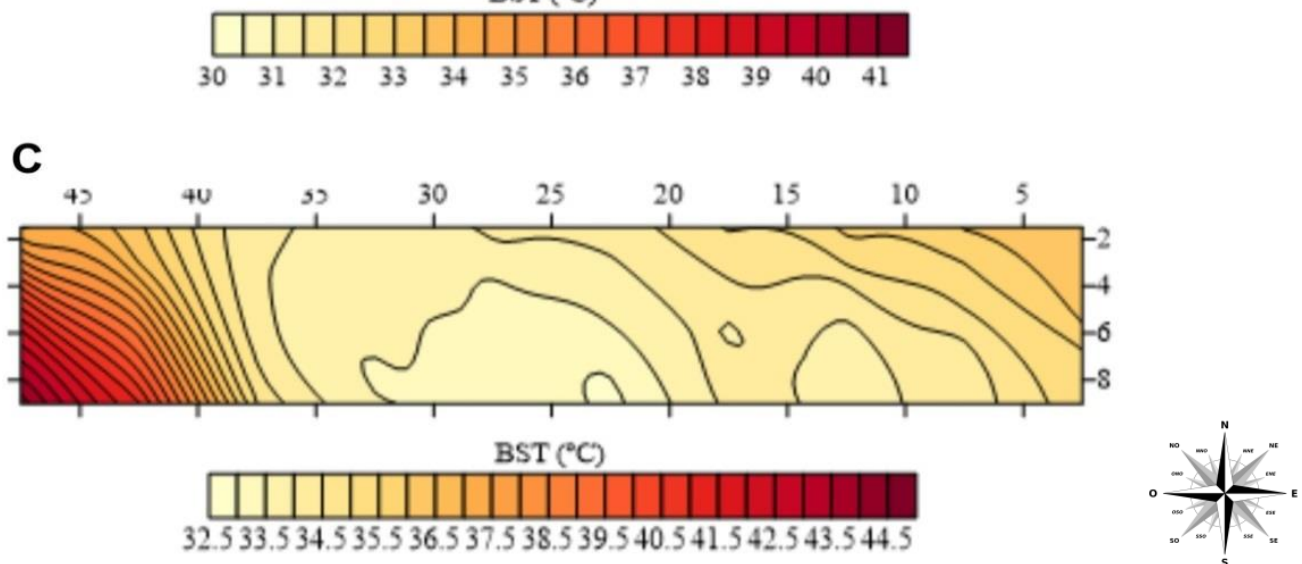

Figure 3. Spatial distribution of the surface temperature of the carnauba straw bed $\left({ }^{\circ} \mathrm{C}\right)$ in the Compost Barn, in the afternoon shift, in the 1st (A), 2nd (B), and 3rd (C) phase.

The space of $9.0 \mathrm{~m}^{2} / \mathrm{cow}$, observed in the second phase, and $9.5 \mathrm{~m}^{2} / \mathrm{cow}$, in the third, suggests that the addition in feces and urine in the bedding may have occurred in a similar way in these phases. In this scenario, the bedding quality parameters would not undergo major changes in a short period of time. For this, we can highlight the evaluation of environmental variables as a complementary parameter, and it was observed that in the afternoon shift, the variables AT, RH, and $\mathrm{WSb}$, did not present a significant difference $(p>0.05)$. However, the thermal performance of the bed (BST and BIT) underwent significant variations ( $\mathrm{p}<0.05)$ between the second and third phases. This result may point out that the challenges for the use of carnauba straw as bedding material in Compost barn are mainly related to the physical and chemical characteristics inherent to the material. The fast degradation during the composting process hindered the adjustments in the management seeking an increase in the useful lifetime of the bed. As alternatives, there is the addition of bedding material, as the carbon source, and the adjustment in the space per cow. During the entire experiment, there was only one bedding 
replacement, which occurred shortly after the second collection phase.

The BIT remained considerably low in all phases (ranging from 39 to $45^{\circ} \mathrm{C}$ ), presenting large heat losses to the upper layer, so that this result did not ensure the proper composting process (Janni et al., 2006). The current study showed that the BIT was affected by increasing barn ambient temperature, as shown in studies by Eckelkamp et al. (2016) and Silva et al. (2020), which may explain the result of the material having presented the internal temperature increase in the third phase, if compared with the second. However, internal temperature values did not present statistically significant difference $(p>0.05)$, when comparing the first and third phase.

The temperature range of 43 to $65^{\circ} \mathrm{C}$ can be considered reasonable for the composting process (On-Farm..., 1992). However, as it is a process in which the bedding composes a material that undergoes partial composting (Russelle et al., 2009), reaching optimum temperatures becomes a challenge for milk producers. Following this fact, research using Compost barn in Brazil, including the present work, reported systems in which the ideal temperature range was not reached (Mota et al., 2019; Piovesan and Oliveira, 2020).

Bedding management in Compost barn systems requires a good balance between moisture ratio, aeration methods, carbon source, and nitrogen increase based on density of animals. Moisture, oxygen, carbon, and nitrogen are the necessary components for an ideal composting process, contributing to adequate adjustments internal temperature of the bed. In this study, the temperature (BIT) between the initial and final phases did not show a statistically significant difference $(p>0.05)$, indicating that the decision to remove the bed at 140 days was not directly influenced by changes in the BIT, or by parameters as the $\mathrm{C} / \mathrm{N}$ ratio, but by the physical aspect of the carnauba straw, which showed accelerated degradation of its particles and signs of compaction in the deeper layers of the bed.

\section{CONCLUSIONS}

Thermal conditions of the bed formed by carnauba straw were affected by barn ambient temperature. The bed surface temperature proved to be favorable to the animals throughout the study, even with the climatic challenges found in the confinement of dairy cattle in the semiarid region and high results $\mathrm{THI}$, while the bedding internal temperature did not reach ideal values to composting processing. Through the geostatistical analysis it is concluded that spatial variability study in CB has useful applications regarding the influence of the facility design on the thermal performance of the bedding materials, so that studies on alternative materials used in the resting area should be considered.

\section{REFERENCES}

BACCARI JÚNIOR, F.; JOHNSON, H.D.; HAHN, G.L. Environmental heat effects on growth, plasma $\mathrm{t}$, and pos the at compensatory effects on Holstein calves. Proc. Soc. Exp. Biol. Med., v.173, p.312-318, 1983.

BARBERG, A.E.; ENDRES, M.I.; JANNI, K.A. Compost dairy barns in Minnesota: a descriptive study. Appl. Eng.Agric., v.23, p.231-238, 2007.

BEWLEY, J.M.; ROBERTSON, L.M.; ECKELKAMP, E.A. 100-Year review: lactating dairy cattle housing management. J.Dairy Sci., v.100, p.10418-10431, 2017.

BLACK, R.A.; TARABA, J.L.; DAY, G.B. et al. Compost bedded pack dairy barn management, performance, and producer satisfaction. J. Dairy Sci., v.96, p.8060-8074, 2013.

COOK, N.B. Symposium review: the impact of management and facilities on cow culling rates. $J$. Dairy Sci., v.103, p.3846-3855, 2020.

DAMASCENO, F.A. Compost barn como uma alternativa para pecuária leiteira. Divinópolis: Adelante, 2020. 396p.

DIMOV, D.; GERGOVSKA, Z.; MARINOV, I. et al. Effect of stall surface temperature and bedding type on comfort indices in dairy cows. Sylwan J., v.161, p.1-15, 2017.

ECKELKAMP, E.A.; TARABA, J.L.; AKERS, K.A. et al. Understanding compost bedded pack barns: Interactions among environmental factors, bedding characteristics, and udder health. Livest. Sci., v.190, p.35-42, 2016.

GOMES, J.A.F.; LEITE, E.R.; CAVALCANTE, A.C.R. et al. Resíduo agroindustrial da carnaúba como fonte de volumoso para a terminação de ovinos. Pesqui. Agropecu. Bras., v.44, p.58-67, 2009. 
HAHN, G.L.; GAUGHAN, J.B.; MADER, T.L. et al. Chapter 5: thermal indices and their applications for livestock environments. In: DESHAZER, J.A. (Ed.). Livestock energetics and thermal environmental management. Michigan: ASABE, 2009. p.113-130.

JANNI, K.A.; ENDRES, M.I.; RENEAU, J.K.; SCHOPER, W.W. Compost dairy barn layout and management recommendations. Appl. Eng. Agric., v.23, p.97-102, 2006.

LESO, L.; CONTI, L.; ROSSI, G.; BARBARI, M. Criteria of design for deconstruction applied to dairy cows housing: a case study in Italy. Agron. Res., v.16, p.794-805, 2018.

LINHARES, A.S.F.; SOARES, D.L.; OLIVEIRA, N.C.T. et al. Respostas fisiológicas e manejo adequado de ruminantes em ambientes quentes. Agropecu. Cient. Semiárido, v.11, p.2733, 2015.

MACHADO, N.A.F.; COSTA, L.B.S.; BARBOSA FILHO, J.A.D. et al. Using infrared thermography to detect subclinical mastitis in dairy cows in compost barn systems. J. Therm. Biol., v.97, p.102881, 2021.

MOTA, V.C.; ANDRADE, E.T.; LEITE, D.F. Bed temperature in compost barns turned with rotary hoe and offset disc harrow. Eng. Agríc., v.39, p.280-287, 2019.

OLIVEIRA, V.C.; DAMASCENO, F.A.; OLIVEIRA, C.E.A. et al. Compost-bedded pack barns in the state of Minas Gerais: architectural and technological characterization. Agron. Res., v.17, p.2016-2028, 2019.

ON-FARM composting handbook. New York: Waste Management Publications, 1992. 187p. (Northeast Regional Agricultural Engineering Servicel-54).

PEIXOTO, M.S.M.; BARBOSA FILHO, J.A.D.; MACHADO, N.A.F. et al. Thermoregulatory behavior of dairy cows submitted to bedding temperature variations in Compost barn systems. Biol. Rhythm Res., v.52, p.1120-1129, 2019.
PIOVESAN, S.M.; OLIVEIRA, D.S. Fatores que influenciam a sanidade e conforto térmico de bovinos em sistemas compost barn. Rev. Vivências, v.16, p.247-258, 2020.

RUSSELLE, M.P.; BLANCHET, K.M.; RANDALL, G.W.; EVERETT, L.A. Characteristics and nitrogen value of stratified bedded pack dairy manure. Crop Manag. Res., v.8,p. $-10,2009$.

SHANE, E.M.; ENDRES, M.I.; JANNI, K.A. Alternative Bedding materials for Compost Bedded Pack Barns in Minnesota: A descriptive study. Appl. Eng. Agric., v.26, p.171-179, 2010.

SILVA, A.M.; GUEDES, M.I.F.; RONDINA, D. Produtos da cadeia produtiva da carnaubeira e seus efeitos na alimentação animal. Ciênc. Anim., v.29, p.65-79, 2019.

SILVA, M.V.; PANDORFI, H.; ALMEIDA, G.L.P. et al. Spatial variability and exploratory inference of abiotic factors in barn compost confinement for cattle in the semiarid. J. Therm. Biol., v.94, p.102782, 2020.

VALENTE, D.A.; SOUZA, C.F.; ANDRADE, R.R. et al. Comparative analysis of performance by cows confined in different typologies of compost barns. Agron. Res., v.18, p.1547-1555, 2020.

VIEIRA, S.R. Geoestatística em estudos de variabilidade espacial do solo. In: NOVAIS, R.F.; ALVAREZ, V.H.; SCHAEFER, C.E.G.R. Tópicos em ciência do solo. (Ed.). Viçosa: Sociedade Brasileira de Ciência do Solo, 2000. p.1-53.

ZIMBACK, C.R.L. Análise espacial de atributos químicos de solos para fins de mapeamento da fertilidade. 2001. 114f. Tese (Livre-Docência) Faculdade de Ciências Agrárias, Universidade Estadual de São Paulo, Botucatu, SP. 